\title{
TANGGUNG JAWAB BIDAN DALAM MENANGANI PASIEN NON KEBIDANAN DI KAITKAN DENGAN MANAJEMEN TERPADU BALITA SAKIT DAN MANAJEMEN TERPADU BAYI MUDA
}

\author{
Rista Dian Anggraini \\ Progam Studi Magister Ilmu Hukum \\ Fakultas Hukum Universitas Hang Tuah Surabaya \\ Email: ristadian94@gmail.com
}

\begin{abstract}
WHO in 2005 has acknowledged that integrated infant management and integrated young infant management approaches are well suited to apply in developing countries in efforts to reduce infant and under-five mortality, mordibity dan disability in infants and toddlers when done in a complete and good manner. The government progam in the Minister of Healt No. 28 of 2017 on the implementation of midwifery pratices does allow midwives of handle infant and toodlers in accordance with the guidelines MTBS and MTBM, but in terms of drug delivery to infants and toddlers midwife has no authority and no competence so that here can happen conflict. In this study the authors examine some problems, namely; 1. Responsibility of the midwife in the administration of drugs to non-midwifes patients associated with MTBS and MTBM. 2. Responsibility of the midwife if the handling that causes death. In this study categorized as normative legal research, the approach used in this study is the legislation approcoach that is not only a norm buat also see how the law can be applied in the community. In this study, health workers against the law can also be subject to sancitions in accordance with the law applicable to the general public. Beside that, in this research also mention about competence and authority if midwife in giving action of MTBS and MTBM.
\end{abstract}

Keywords: MTBS and MTBM, Permenkes No. 28 of 2017, midwives competence, authority of midwife.

\begin{abstract}
Abstrak
WHO (World Health Organization) tahun 2005 telah mengakui bahwa pendekatan Manajemen Terpadu Balita Sakit (yang selanjutnya disingkat dengan MTBS) dan Manajemen Terpadu Bayi Muda (yang selanjutnya disingkat dengan MTBM) sangat cocok diterapkan di Negara-negara berkembang dalam upaya menurunkan angka kematian, kesakitan dan kecacatan pada bayi dan balita bila dilaksanakan dengan lengkap dan baik. Progam pemerintah dalam Permenkes No. 28 tahun 2017 tentang penyelenggaraan praktik kebidanan memang memperbolehkan bidan dalam menangani bayi dan balita sakit sesuai dengan pedoman MTBM dan MTBS, tetapi dalam hal pemberian obat terhadap bayi dan balita sakit bidan tidak memiliki wewenang dan tidak memiliki kompetensi sehingga disini dapat terjadi konflik. Dalam penelitian ini penulis mengkaji beberapa masalah yaitu; 1. Tanggungjawab bidan dalam pemberian obat kepada pasien non kebidanan dikaitkan dengan MTBS dan MTBM. 2. Peran dan tanggung jawab Bidan jika melakukan penanganan yang salah yang menyebabkan meninggal dunia. Dalam penelitian ini di kategorikan sebagai penelitian hukum normatif, Pendekatan yang digunakan dalam penelitian ini ialah pendekatan perundangundangan yaitu bukan hanya bersifat norma tapi juga melihat bagaimana hukum dapat di terapkan di masyarakat. Dalam penelitian ini tenaga kesehatan yang melawan hukum juga dapat dikenakan sanksi sesuai dengan hukum yang berlaku bagi masyarakat umum. Disamping itu, dalam penelitian ini juga mencantumkan mengenai kompetensi dan
\end{abstract}


kewenangan bidan dalam memberikan tindakan MTBS dan MTBM.

Kata Kunci: MTBS dan MTBM, Permenkes No. 28 tahun 2017, kompetensi bidan, kewenangan bidan.

\section{PENDAHULUAN}

Angka kematian ibu bersalin sebagai salah satu indikator kesehatan ibu maternal (ibu dalam masa kehamilan, persalinan dan nifas) sangat penting untuk melihat keberhasilan program kesehatan kebidanan. Pada saat ini angka kematian ibu bersalin sangat tinggi diperkirakan lebih kurang 20.000 kematian ibu / tahun hasil penelitian mengemukakan kematian ibu bersalin disebabkan oleh perdarahan, keracunan kehamilan dan infeksi.

Bidan merupakan tenaga kesehatan yang salah satu tugas utamanya melakukan pertolongan persalinan. Pertolongan persalinan sebagian besar 90 $\%$ dilakukan oleh yang sudah maupun terlatih dilaksanakan di rumah, salah satu pengelolaan program Kesehatan Ibu dan Anak yaitu meningkatkan pertolongan oleh tenaga professional (bidan) yang secara terus-menerus meningkat walaupun persalinan tetap di layani secara selektif. ${ }^{1}$ Untuk dapat melaksanakan pertolongan persalinan dengan lancar dan aman di rumah, peralatan yang mutlah dimiliki

\footnotetext{
${ }^{1}$ Emmy Latifah, "Harmonisasi Kebijakan Pengentasan Ke-miskinan di Indonesia Yang Berorientasi Pada Millen-nium Development Goals", Jurnal Dinamika Hukum, Volume 11, Nomor 3, September 2011, hlm. 403
}

bidan yaitu, bidan kit, atau tas persalinan bidan harus mengetahui isi dan pemeliharaan bidan kit / tas persalinan tersebut dan dari segi aturan hukum profesi bidan juga di atur di dalam Peraturan Menteri Kesehatan No 28 Tahun 2017 tentang Izin dan Penyelenggaraan Praktik Bidan. ${ }^{2}$

Setiap tahunnya lebih dari sepuluh juta anak di dunia meninggal sebelum mencapai usia 5 tahun. Lebih dari stengahnya disebabkan oleh lima kondisi yang sebenarnya dapat dicegah dan diobati antara lain pneumonia, diare, malaria, campak, dan malnutrisi. Sering kali kombinasi dari beberapa penyakit lain.

WHO tahun 2005 telah mengakui bahwa pendekatan Manajemen Terpadu Balita Sakit (yang selanjutnya disingkat dengan MTBS) dan Manajemen Terpadu Bayi Muda (yang selanjutnya disingkat dengan MTBM) sangat cocok diterapkan di Negara-negara berkembang dalam upaya menurunkan angka kematian, kesakitan dan kecacatan pada bayi dan balita bila dilaksanakan dengan lengkap

2 Peraturan Menteri Kesehatan No 28 Tahun 2017 tentang Izin dan Penyelenggaraan Praktik Bidan. 
dan baik. Karena pendekatan MTBS dan MTBM tergolong lengkap untuk mengantisipasi penyakit-penyakit yang sering menyebabkan kematian pada balita di dunia, termasuk pneumonia. Dikatakan lengkap karena meliputi upaya preventif (pencegahan penyakit), perbaikan gizi, upaya promotif (berupa konseling) dan upaya kuratif (pengobatan) . Menurut data laporan rutin yang dihimpun dari Dinas Kesehatan Kota Semarang seluruh Indonesia melalui Pertemuan Nasional Program Kesehatan Anak tahun 2012, jumlah puskesmas yang melaksanakan MTBS hingga akhir tahun 2012 sebesar $60 \%$.

Dalam beberapa kasus dibidang kesehatan salah satunya adalah malpraktik yang bisa dikenakan pidana kepada dokter atau tenaga medis lainnya. ${ }^{3}$

Disinilah kita harus memastikan bahwa semua penolong persalinan mempunyai pengetahuan, ketrampilan dan alat untuk memberikan pertolongan yang aman dan bersih. Adanya etika pelayanan bisa memberikan kepedulian, kewajiban dan tanggung jawab moral yang dimiliki oleh bidan tentang hidup dan makna

\footnotetext{
${ }^{3}$ Yati. Nurhayati, "THE APPLICATION OF BALANCE IDEA IN SETTLEMENT OF DOCTOR MALPRACTICE CASE THROUGH PENAL MEDIATION." The 2nd Proceeding "Indonesia Clean of Corruption in 2020" (2017), hlm. 111.
}

kesehatan selama daur kehidupan yang sesuai dengan MTBS dan MTBM.

Ketika kebutuhan masyarakat terhadap pelayanan kesehatan meningkat, terutama pelayanan bidan, tidak diimbangi oleh keahlian dan keterampilan bidan untuk membentuk suatu mekanisme kerja pelayanan yang baik. Masih sering dijumpai pelayanan bidan tidak sesuai dengan wewenangnya dan juga kurangnya perlindungan hukum terhadap bidan.

Banyak diketemuaan kewenangan bidan melebihi kewengannnya karena dituntut merawat pasien yang rujuk ke puskesmas antara lain, sakit demam, malaria, batuk, flu dan berbagai macam penyakit lainnya, bukanhanya tugas pooknya yaitu membantu pasien yang melahirkan. Kejadian tersebut sebagian bukan wewenang bidan dalam melakukan praktiknya dan seharusnya dirujuk ke tingkat yang lebih tinggi untuk memperoleh pertolongan dan sesuai dengan wewenangnya atau tanggung jawabnya. Seperti pemberian obat pada bayi yang sakit walaupun berpedoman dengan MTBS dan MTBM tetapi hal tersebut bertentangan dengan Peraturan Pemerintah Nomor 51 Tahun 2009 tentang Pekerjaan Kefarmasian Pasal 21 ayat (2) ang berbunyi "Penyerahan dan pelayanan obat berdasarkan resep dokter 
dilaksanakan oleh Apoteker. ${ }^{4}$ Oleh karena itu, pentingnya penelitian ini adalah dapat ditegakannya penegakan hukum terhadap pelanggaran bidan dan akibat hukumnya, karena seorang bidan sudah mempunyai wewenang dan standar praktik bidan dalam hal ini guna membatasi wewenang sesuai dengan peraturan yang berlaku.

$$
\text { Jenis dari penelitian ini }
$$
dikategorikan sebagai penelitian hukum normative, yaitu penelitian yang dilakukan dengan mengkaji ketentuan perundang-undangan serta melihat fakta hukum yang terjadi dilapangan. Secara hakikat, ilmu hukum berusaha untuk menampilkan hukum secara integral. ${ }^{5}$ Metode pendekatan yang digunakan yaitu metode perundang-undangan yang memandang hukum bukan saja sebagai perangkat kaidah tetapi juga melihat bagaimana hukum itu dapat di terapkan di tengah-tengah masyarakat. Dalam penelitian ini terdapat tiga sumber bahan hukum yaitu, primer, sekunder dan tersier. Untuk memperoleh pemahaman atas masalah yang terjadi, digunakan metode kajian Induktif. Data tersebut kemudian

\footnotetext{
${ }^{4}$ Peraturan Pemerintah Nomor 51 Tahun 2009 Tentang Pekerjaan Kefarmasian Pasal 21 ayat (2).

, Nurhayati, Yati. "Perdebatan antara Metode Normatif dengan Metode Empirik dalam Penelitian Ilmu Hukum Ditinjau dari Karakter, Fungsi, dan Tujuan Ilmu Hukum." Al Adl: Jurnal Hukum5.10 (2013), hlm. 15.
}

akan dipaparkan secara deskriptif (dengan kata-kata), sehingga memperoleh gambaran yang jelas masalah yang diteliti.

\section{PEMBAHASAN}

Tanggung Jawab Bidan Dalam Pemberian Obat Kepada Pasien Non Kebidanan Dikaitkan Dengan MTBS Dan MTBM

Dalam Undang-Undang Tahun 2014 tentang Tenaga Kesehatan (UU Tenaga Kesehatan) ${ }^{6}$ terbaru, tenaga kebidanan adalah salah satu jenis tenaga kesehatan. Sebagai salah satu tenaga kesehatan, bidan dalam menjalankan praktik harus sesuai dengan kewenangan yang didasarkan pada kompetensi yang dimilikinya (lihat Pasal 62 ayat (1) UU Tenaga Kesehatan). Menurut penjelasan Pasal 62 ayat (1) huruf c UU Tenaga Kesehatan, yang dimaksud dengan "kewenangan berdasarkan kompetensi" adalah kewenangan untuk melakukan pelayanan kesehatan secara mandiri sesuai dengan lingkup dan tingkat kompetensinya, antara lain untuk bidan adalah ia memiliki kewenangan untuk melakukan pelayanan kesehatan ibu, pelayanan kesehatan anak, dan pelayanan

6 Undang-Undang Republic Indonesia, tentang Tenaga Kesehatan, pasal 11 ayat (1) dan (5). Tahun 2014. 
kesehatan reproduksi perempuan dan keluarga berencana ${ }^{7}$.

Jika bidan tidak melaksanakan ketentuan dalam Pasal 62 ayat (1) UU Tenaga Kesehatan, ia dikenai sanksi administratif. Ketentuan sanksi ini diatur dalam Pasal 82 ayat (1) UU Tenaga Kesehatan $^{8}$. Sanksi yang dikenal dalam UU Tenaga Kesehatan adalah sanksi administratif, yakni sanksi ini dijatuhkan jika bidan yang bersangkutan dalam menjalankan praktiknya tidak sesuai dengan kompetensi yang dimilikinya. Dengan kata lain, jika memang memberikan obat atau suntikan bukanlah kompetensi yang dimilikinya, maka sanksi yang berlaku padanya adalah sanksi administratif bukan sanksi pidana. Akan tetapi, apabila ternyata pertolongan persalinan itu merupakan suatu kelalaian berat yang menyebabkan penerima pelayanan kesehatan menderita luka berat, maka bidan yang bersangkutan dapat dipidana dengan pidana penjara paling lama 3 (tiga) tahun. Sedangkan jika kelalaian berat itu mengakibatkan kematian, bidan tersebut dipidana dengan pidana penjara paling lama 5 (lima) tahun (lihat Pasal 84 UU Tenaga Kesehatan).

\footnotetext{
7 Undang-Undang Tenaga Kesehatan, Pasal 65 ayat (1) huruf c.

${ }_{8}$ Undang-undang Tenaga Kesehatan, pasal 82 ayat (1).
}

Pelayanan kesehatan yang dilakukan oleh bidan atau perawat dilakukan di luar kewenangannya karena mendapat pelimpahan wewenang. Hal ini disebut dalam Pasal 65 ayat (1) UU Tenaga Kesehatan yang berbunyi bahwa dalam melakukan pelayanan kesehatan, Tenaga Kesehatan dapat menerima pelimpahan tindakan medis dari tenaga medis.

Adapun yang dimaksud dengan tenaga medis dalam Pasal 11 ayat (2) UU Tenaga Kesehatan adalah dokter, dokter gigi, dokter spesialis, dan dokter gigi spesialis. Kemudian yang dimaksud tenaga kesehatan yang disebut dalam penjelasan pasal di atas antara lain adalah bidan dan perawat ${ }^{9}$.

Selain itu, bidan yang menjalankan program pemerintah berwenang melakukan pelayanan kesehatan meliputi pemberian alat kontrasepsi suntikan, alat kontrasepsi dalam rahim, dan memberikan pelayanan alat kontrasepsi bawah kulit (Pasal 13 ayat (1) huruf a Permenkes $1464 / 2010)^{10}$.

Melihat pada ketentuan di atas, sehubungan dengan pertolongan persalinan dengan vakum ekstraksi oleh bidan, dapat dilihat bahwa sanksi pidana

\footnotetext{
9 Undang-undang Tenaga Kesehatan, pasal 11 ayat (2), tentang Tenaga Medis.

${ }^{10}$ Ibid, pasal 13 ayat (1).
} 
akan diberikan kepada bidan jika tindakan yang dilakukannya kepada pasien merupakan suatu kelalaian berat yang mengakibatkan luka berat atau kematian kepada pasien.

Kode etik diharapkan mampu menjadi sebuah pedoman yang nyata bagi para bidan dalam menjalankan tugasnya. Tapi pada kenyataannya para bidan masih banyak yang melakukan pelanggaran terhadap kode etiknya sendiri dalam pemberian pelayanan terhadap masyarakat.

Bidan yang menolong persalinan banyak melakukan penyimpangan pelayanan kebidanan yang tidak seharusnya dilakukan oleh bidan seperti teknik kristeller, episiotomy yang terlalu lebar, bayi meninggal, perdarahan karena robekan uterus dan akhirnya dirujuk dan dilakukan tindakan histerektomi. Mestinya bidan sudah mempunyai ketrampilan dalam pertolongan persalinan sehingga penyimpangan-penyimpangan ini tidak terjadi sebelum melakukan pertolongan bidan juga harus melihat penapisan awal terlebih dahulu apakah pasien ini beresiko, bila menemukan pasien ini beresiko mestinya bidan tersebut melakukan rujukan terencana ${ }^{11}$.

11 http://elisevaraniriang.blogspot.co.id/2014/02/penyimpangan-kode-etik-bidan diakeses pada 9 Januari 2018.
Bentuk dari pelanggaran ini bermacam-macam. Seperti pemberian pelayanan yang tidak sesuai dengan kewenangan bidan yang telah diatur dalam Permenkes

Nomor 1464/Menkes/Per/X/2010 tentang Izin dan Penyelenggaraan Praktik Bidan ${ }^{12}$. Sanksi yang diberikan kepada bidan bisa berupa pencabutan ijin praktek bidan, pencabutan SIPB sementara, atau bisa juga berupa denda.Selain itu bidan juga bisa mendapat sanksi hukuman penjara jika melakukan pelanggaran terhadap peraturan perundang-undangan. Apabila seorang bidan melakukan pelanggaran kode etik maka penyelesaian atas hal tersebut dilakukan oleh wadah profesi bidan yaitu IBI. Sedangkan apabila seorang bidan melakukan pelanggaran yuridis dan dihadapkan ke muka pengadilan. Maka IBI melalui MPA dan MPEB wajib melakukan penilaian apakah bidan tersebut telah benar-benar melakukan kesalahan. Apabila menurut penilaian MPA dan MPEB kesalahan atau kelalaian tersebut terjadi bukan karena kesalahan atau kelalaian bidan, dan bidan tersebut telah melakukan tugasnya sesuai dengan standar profesi, maka IBI melalui MPA wajib memberikan bantuan hukum kepada

${ }^{12}$ Permenkes No. 1464 tentang Izin dan Penyelenggaraan Prakrik Bidan. 
bidan tersebut dalam menghadapi tuntutan atau gugatan di pengadilan.

\section{Menganalisa Kewenangan Bidan}

Dalam Pemberian Obat Pada Bayi

Progam pemerintah dalam

Permenkes No. 28 tahun 2017 tentang penyelenggaraan praktik kebidanan memang memperbolehkan bidan dalam menangani bayi dan balita sakit sesuai dengan pedoman MTBM dan MTBS karena hal tersebut dapat sangat membantu dalam mengurangi angka kematian bayi dan balita. Tetapi dalam hal pemberian obat terhadap bayi dan balita sakit bidan tidak memiliki wewenang dan tidak memiliki kompetensi sehingga disini dapat terjadi konflik jika terjadi kesalahan dalam pemberian obat, terutama dalam pedoman MTBS dan MTBM obat yang sering di gunakan adalah antibiotik. Antibiotik sendiri jika di berikan tidak sesuai usia dan sesuai dosis maka akan berakibat sebaliknya yaitu dapat melemahkan system kekebalan tubuh manusia yang akan mengakibatkan lebih mudah penyakit masuk kedalam tubuh bayi dan balita tersebut.

Sesuai dengan Peraturan Pemerintah Nomor 51 Tahun 2009 tentang pekerjaan kefarmasian bahwa yang berkompetensi dibidang obat adalah profesi farmasi. Tetapi dalam keadaan tertentu seperti kegawatdaruratan dan tidak adanya tenaga kesehatan lain didaerah tempat bidan tersebut praktek (tidak adanya tenaga kesehatan lain didaerah tersebut dinyatakan dengan keterangan dari Dinas Kesehatan setempat). Bidan boleh melakukan penanganan atau pemberian obat terhadap bayi dan balita tetapi sesuai dengan panduan MTBS dan MTBM dan sesuai dengan batasan-batasan penyakit yang sudah ditentukan. Penyakit yang dapat ditangani oleh bidan sesuai dengan MTBS dan MTBM adalah diare, demam, masalah telinga, status gizi, dan anemia, dengan catatan masih dalam klasifikasi rendah dan sedang, jika sudah pada tahap klasifikasi yang berat maka pasien tersebut harus segera dirujuk.

Hierarki Peraturan Perundangundangan saat ini, Undang-Undang No. 12 tahun 2011 pasal 7 yang saat ini diberlakukan: ${ }^{13}$

1. Undang-Undang Dasar Negara Republik Indonesia tahun 1945;

2. Ketetapan Majelis Permusyawaratan Rakyat;

3. Undang-Undang/ Peraturan Pemerintah pengganti UndangUndang;

4. Peraturan Pemerintah;

5. Peraturan Presiden;

\footnotetext{
${ }^{13}$ Undang-Undang No.12 Tahun 2011.
} 
6. Peraturan Daerah Provinsi;

7. Peraturan Daerah Kabupaten/Kota. Peraturan Menteri dalam UndangUndang No. 12 tahun 2011 tentang Pembentukan Peraturan Undang-Undang, pasal 8 ayat (1) Undang-Undang No. 12/2011 yang menegaskan ${ }^{14}$ :

"Jenis Peraturan Perundang-undangan selai sebagaimana dimaksud dalam pasal 7 ayat (1) mencakup Peraturan Dewan Perwakilan Rakyat, Dewan Perwakilan Daerah, Mahkamah Agung, Mahkamah Konstitusi, Badan Pemeriksa Keuangan, Komisi Yudisial, Bank Indonesia, Menteri, Bdan Lembaga, atau komisi yang dibentuk setingkat dengan Undangundang, Dewan Perwakilan Rakyat Daerah Kabupaten/Kota, Bupat/Walikota, Kepala Desa, atau setingkat pasal diatas mencerminkan bahwa keberadaan peaturan Menteri sebagai salah satu jenis peraturan Perundang-Undangan. Dengan demikian Peraturan Menteri setelah berlakunya Undang-Undang No. 12/2011 tetap diakui keberadaannya".

Peraturan Menteri yang dibentuk atas dasar perintah Undang-Undang tersebut di kategorikan sebagai peraturan Peraturan Perundang-Undangan atas dasar delegasi. Dengan demikian, secara umum peraturan perundang-undangan delegasi adalah peraturan perundang-undangan yang dibentuk atas dasar perintah peraturan perundang-undangan yang lebih tinggi.

14 Undang-Undang No.12 Tahun 2011 tentang Pembentukan Peraturan Undang-Undang, Pasal 8.
Jadi, Permenkes No. 28 tahun 2017 tentang penyelenggaraan praktik kebidanan kedudukannya berada lebih tinggi dari Peraturan Pemerintah No. 51 Nomor Tahun 2009 tentang pekerjaan kefarmasian, hal ini dapat menjadi suatu payung hukum bagi seorang bidan dalam menangani pasien yaitu balita dan bayi dalam pemberian obat sesuai dengan buku panduan MTBS dan MTBM dan sesuai dengan batasan kompetensi pengetahuan bidan tentang obat.

\section{Tanggung Jawab Bidan Dalam}

\section{Menangani Balita Yang Menyebabkan}

\section{Kematian}

Maraknya kasus dugaan malpraktik belakangan ini, khususnya di bidang perawatan ibu dan anak, menjadi peringatan dan sekaligus sebagai dorongan untuk lebih memperbaiki kualitas pelayanan. Melaksanakan tugas dengan berpegangan pada janji profesi dan tekad untuk selalu meningkatkan kualitas diri perlu dipelihara. Kerja sama yang melibatkan segenap tim pelayanan kesehatan perlu dieratkan dengan kejelasan dalam wewenang dan fungsinya.

Khusus berkenaan dengan wewenang bidan diatur di dalam Peraturan Menteri Kesehatan Nomor 363/Men.Kes/Per/IX/1980 tentang Wewenang Bidan. Dari sudut hukum, 
profesi tenaga kesehatan dapat di minta pertangungjawaban berdasarkan hukum perdata, hukum pidana, maupun hukum administrasi.

Tanggung jawab dari segi hukum perdata didasarkan pada ketentuan Pasal 1365 BW, atau kitab Undang-Undang Hukum Perdata ${ }^{15}$. Apabila tenaga kesehatan dalam melaksanakan tugasnya melakukan tindakan yang mengakibatkan kerugian pada pasien, maka tenaga kesehatan tersebut dapat digugat oleh pasien atau keluarga yang merasa dirugikan itu berdasarkan pasal $1365 \mathrm{BW}$, yang berbunyi sebagai berikut : 21 karena kesalahannya menerbitkan kerugian yang disebabkan kelalaian atau kurang hatihati.

Dari segi hukum pidana juga seorang tenaga kesehatan dapat dikenai ancaman Pasal 351 Kitab Undang-Undang Hukum Pidana ${ }^{16}$. Ancaman pidana tersebut dikenakan kepada seseorang (termasuk tenaga kesehatan) yang karena kelalaian atau kurang hati-hati menyebabkan orang lain (pasien) cacat atau bahkan sampai meninggal dunia.

Bidan diberikan kewenangan melakukan pelayanan kesehatan sesuai

${ }^{15}$ Kitab Undang-Undang Hukum Perdata, Buergerlijk Wetboek, diterjemahkan oleh R. Subekti dan R. Tjitrosudibio, Pradaya Paramita, Jakarta. 2004. pasal. 1365. pasal 351 . kompetensinya. Pelayanan kebidanan adalah bagian integral dari sistem pelayanan kesehatan yang diberikan oleh bidan yang telah terdaftar (teregister) yang dapat dilakukan secara mandiri, kolaborasi atau rujukan. Pelayanan Kebidanan merupakan bagian integral dari pelayanan kesehatan, yang diarahkan untuk mewujudkan kesehatan keluarga, sesuai dengan kewenangan dalam rangka tercapainya keluarga kecil bahagia dan sejahtera. Sasaran pelayanan kebidanan adalah individu, keluarga, dan masyarakat yang meliputi upaya peningkatan, pencegahan, penyembuhan dan pemulihan.

Selain kewenangan tersebut, kewenagan bidan lainnya didapat dari pelimpahan kewenangan, pelimpahan kewenangan bagi bidan menurut Pasal 22 Permenkes Ijin dan Penyelenggaraan Praktik Bidan menyatakan bahwa selain kewenangan sebagaimana yang telah dijelaskan sebelumnya, bidan memiliki kewenangan memberikan pelayanan berdasarkan penugasan dari pemerintah sesuai kebutuhan; dan/atau pelimpahan wewenang melakukan tindakan pelayanan kesehatan secara mandat dari dokter.

Pelayanan kesehatan anak diberikan pada bayi baru lahir, bayi, anak balita, dan anak prasekolah. Dalam memberikan pelayanan kesehatan anak 
bidan berwenang melakukan pelayanan neonatal esensial meliputi inisiasi menyusui dini, pemotongan dan perawatan tali pusat, pemberian suntikan vitamin $\mathrm{K} 1$, pemberian imunisasi $\mathrm{B} 0$, pemeriksaan fisik bayi baru lahir, pemantauan tanda bahaya, pemberian tanda identitas diri, dan merujuk kasus yang tidak dapat ditangani dalam kondisi stabil dan tepat waktu ke Fasilitas Pelayanan Kesehatan yang lebih mampu.; Penanganan kegawatdaruratan, dilanjutkan dengan perujukan meliputi penanganan awal asfiksia bayi baru lahir melalui pembersihan jalan nafas, ventilasi tekanan positif, dan/atau kompresi jantung; penanganan awal hipotermia pada bayi baru lahir dengan BBLR melalui penggunaan selimut atau fasilitasi dengan cara menghangatkan tubuh bayi dengan metode kangguru; penanganan awal infeksi tali pusat dengan mengoleskan alkohol atau povidon iodine serta menjaga luka tali pusat tetap bersih dan kering; dan membersihkan dan pemberian salep mata pada bayi baru lahir dengan infeksi gonore (GO). Dan pemantauan tumbuh kembang bayi, anak balita, dan anak prasekolah meliputi kegiatan penimbangan berat badan, pengukuran lingkar kepala, pengukuran tinggi badan, stimulasi deteksi dini, dan intervensi dini peyimpangan tumbuh kembang balita dengan menggunakan Kuesioner Pra Skrining Perkembangan (KPSP).serta konseling dan penyuluhan meliputi pemberian komunikasi, informasi, edukasi (KIE) kepada ibu dan keluarga tentang perawatan bayi baru lahir, ASI eksklusif, tanda bahaya pada bayi baru lahir, pelayanan kesehatan, imunisasi, gizi seimbang, PHBS, dan tumbuh kembang.

\section{Menganalisa Perlindungan Hukum Bagi Bidan}

Tenaga kesehatan merupakan komponen utama pemberi pelayanan kesehatan kepada masyarakat dalam rangka tercapainya tujuan pembangunan kesehatan yang sesuai dengan tujuan nasional sebagaimana diamanatkan oleh konstitusi. Selaku komponen utama pemberi pelayanan kesehatan tentunya keberadaan, peran dan tanggung jawab tenaga kesehatan sangatlah penting dalam kegiatan pembangunan kesehatan serta terlindungi baik bagi tenaga kesehatan itu sendiri maupun bagi masyarakat yang menerima pelayanan kesehatan tersebut tentu perlu pengaturan yang dituangkan dalam bentuk peraturan perundangundangan.

Undang-undang Nomor 36 Tahun 2009 terdiri dari 22 bab dan 205 pasal, 
dalam pasal 23 ayat (3) yang berbunyi ${ }^{17}$ : "Dalam menyelenggarakan pelayanan kesehatan, tenaga kesehatan wajib memiliki izin dari pemerintah". Dalam pasal 23 diatas menjelaskan tenaga kesehatan dalam melakukan pelayanan kesehatan serta tugasnya, tenaga kesehatan harus memiliki izin baik berupa SIK (Surat Ijin Kerja) atau SIP (Surat Ijin Praktek) dari pemerintah.

Pasal 27

(1) Tenaga kesehatan mendapatkan imbalan berhak perlindungan hukum dan melaksanakan tugas sesuai dengan profesinya.

(2) Tenaga kesehatan dalam melaksanakan tugasnya berkewajiban mengembangkan dan meningkatkan pengetahuan dan keterampilan yang dimiliki.

Keberadaan bidan di Indonesia sangat diperlukan dalam upaya meningkatkan kesejahteraan ibu dan janinnya, salah satu upaya yang dilakukan oleh pemerintah adalah mendekatkan pelayanan kebidanan kepada setiap ibu yang membutuhkannya. Pada tahun 1993 WHO merekomendasikan agar bidan di bekali pengetahuan dan keterampilan penanganan kegawatdaruratan kebidanan yang relevan. Untuk itu pada tahun 1996 Depkes telah menerbitkan Permenkes No. 572/PER/Menkes/VI/96 yang memberikan

${ }^{17}$ Undang-Undang No 36 tentang Sumber Daya Bidang Kesehatan tahun 2009. wewenang dan perlindugan bagi bidan dalam melaksanakan tindakan penyelamatan jiwa ibu dan bayi baru lahir.

Kegawatan suatu yang menimpa seseorang yang dapat menimbulkan proses mengancam jiwa, dalam arti pertolongan tepat, cermat dan cepat bila tidak dapat menyebabkan seseorang meninggal atau cacat (seri PPGD/GELS, Materi Teknis Medis Standar Depkes 2003).

Sejak tahun 2000 Kementerian Kesehatan RI telah mengembangkan konsep Sistem Penanggulangan Gawat Darurat Terpadu (SPGDT) memadukan penanganan gawat darurat mulai dari tingkat pra rumah sakit sampai tingkat rumah sakit dan rujukan antara rumah sakit dengan pendekatan lintas progam dan multisektoral. Penanggulangan gawat darurat menekan respon cepat dan tepat dengan prinsip Time Saving is Life and Limb Saving. Public Safety Care (PSC) sebagai ujung tombak safe community adalah sarana public/masyarakat yang merupakan perpaduan dari dari unsur pengamanan (kepolisian) dan unsur penyelamatan. PSC merupakan penanganan pertama kegawatdaruratan yang membantu memperbaiki pelayanan pra RS untuk menjamin respons cepat dan tepat untuk menyelamatkan nyawa dan mencegah kecacatan. 
Undang-undang penanggulangan bencana Nomor 24 tahun 2007 dalam Bab I Tentang ketentuan umum pasal 1 ayat (10), ${ }^{18}$ "Tanggap darurat bencana adalah serangkaian kegiatan yang dilakukan dengan segera pada saat kejadian bencana untuk menangani dampak buruk yang ditimbulkan yang meliputi kegiatan penyelamatan dan evakuasi korban, harta benda, pemenuhan kebutuhan dasar, perlindungan pengurusan pengungsi, serta pemulihan sarana dan pra sarana".

Undang-undang Kesehatan Nomor 36 tahun 2009 Pasal 32

(1) Dalam keadaan darurat fasilitas pelayanan kesehatan baik pemerintah maupun swasta wajib memberikan pelyanaan kesehatan bagi penyelamatan nyawa pasien dan pencegahan kecacatan terlebih dahulu.

(2) Dalam keadaan darurat fasilitas pelayanan kesehatan baik pemerintah maupun swasta dilarang menolak pasien dan/atau meminta uang muka.

Profesi kesehatan (tenaga kesehatan) seperti perawat, bidan dan dokter dan profesi lainnya mempunyai tanggung jawab moral untuk memberikan pertolongan pada kasus kasus kegawat daruratan dan bencana, yang disebut Tenaga Kesehatan dalam Undang-undang Kesehatan Nomor 36 Tahun 2009 Bab I

18 Undang-Undang Nomor 24 tentang Penanggulangan Bencana Tahun 2007.
Ketentuan Umum Pasal 1 ayat $(6)^{19}$ : "Setiap orang yang mengabdikan diri dalam bidang kesehatan serta memiliki pengetahuan dan/atau keterampilan melalui pendidikan di bidang kesehatan yang untuk jenis tertentu memerlukan kewenangan untuk melakukan upaya kesehatan". Dalam Peraturan Pemerintah Republik Indonesia, Nomor 36 Tahun 1996 tentang Tenaga Kesehatan bidan adalah termasuk sebagai tenaga keperawatan.

Berdasarkan Kepmenkes RI Nomor 1239/Menkes/SK/XI/2001 Tentang Registrasi dan Praktik Keperawatan, pasal 20 ayat $(1)^{20}$ :

"Dalam darurat yang mengancam jiwa seseorang/pasien, perawat berwenang untuk melakukan pelayanan kesehatan diluar kewenangannya sebagaimana yang dimaksud dalam pasal 15".

Pelayanan dalam keadaan darurat sebagaimana dimaksud dalam ayat (1) ditujukan untuk penyelamatan jiwa.

Dalam perkembangan hukum kesehatan saat ini muncul juga wacara mediasi penal sebagai bentuk perlindungan terhadap tenaga kesehatan. 21

\footnotetext{
20 Kepmenkes RI Nomor 1239/Menkes/SK/XI/2001 tentang Registrasi Praktik Keperawatan, Pasal 20.

${ }^{21}$ SARI, N., HAITI, D., \& IFRANI, I. (2016). Mediasi Penal sebagai Alternatif Penyelesaian Perkara Tindak Pidana Lingkungan Hidup pada
} Tahun 2009.

${ }^{19}$ Undang-Undang Kesehatan Nomor 36 


\section{PENUTUP}

1. Permenkes No. 28 tahun 2017 tentang penyelenggaraan praktik kebidanan kedudukannya berada lebih tinggi dari Peraturan Pemerintah No. 51 Nomor Tahun 2009 tentang pekerjaan kefarmasian, hal ini dapat menjadi suatu payung hukum bagi seorang bidan dalam menangani pasien yaitu balita dan bayi dalam pemberian obat sesuai dengan buku panduan MTBS dan MTBM dan sesuai dengan batasan kompetensi pengetahuan bidan tentang obat.

2. Undang-undang Kesehatan Nomor 36 Tahun 2009 Bab I Ketentuan Umum Pasal 1 ayat (6) Pasal ini mempertegas bahwa petugas kesehatan wajib melakukan upaya kesehatan termasuk dalam pelayanan gawat darurat yang terjadi baik dalam pelayanan sehari-hari maupun dalam keadaan bencana. Undang-undang Nomor 36 Tahun 2009 terdiri dari 22 bab dan 205 pasal 27, tenaga kesehatan berhak mendapatkan perlindungan hukum apabila pasien sebagai

Lahan Basah di Provinsi Kalimantan Selatan. Al Adl: Jurnal Hukum, Volume 8 Issue 1, 2016, hlm. 1. konsumen

kesehatan

menuduh/merugikan tenaga kesehatan dimana tenaga kesehatan sudah melakukan tugas sesuai ke ahliannya serta kewajiban mengembangkan dan meningkatkan pengetahuan dan keterampilan dimaksudkan agar tenaga kesehatan yang bersangkutan dapat memberikan pelayanan yang bermutu sesuai dengan perkembangan ilmu pengetahuan dan teknologi baru.

\section{DAFTAR PUSTAKA}

\section{Buku}

Bagir Manan, 2003, Teori Politik dan Konstitusi, Yogyakarta: Fakultas Hukum UII Press

B.Hestu, Cipto Handoyo, 2009, Hukum Tata Negara Indonesia "Menuju Kosolidasi Sistem Demokrasi, Universitas Admajaya, Jakarta.

Estiwidani.D, 2007, Peran dan Tanggung Jawab Bidan dalam Menangani Pasiennya di Rumah Sakit, Sinar Pustaka: Jakarta.

Freed Kerlinger, N., 1996, Asas-asas Penelitian Behavioral, Edisi Indonesia, Gajah Mada University Press. Yogyakarta.

Kemenkes, 2013, Buku Saku Pelayanan Kesehatan Ibu di Fasilitas Kesehatan Dasar dan Rujukan, edisi pertama. 
Kementrian Kesehatan Republik Indonesia, 2011, Pedoman Pelayanan Kefarmasian Untuk Terapi Antibiotik.

Michael Zwell dalam Wibowo, 2011, Kompetisi perawat dalam menangani pasien di rumah sakit, Gramedia, Jakarta.

Miller, Rankin dan Neathey, Praktek kedokteran di Indonesia, Buku Kompas, Jakarta.

Nazriah, 2009, Praktek Kebidanan di Indonesia, Gramedia, Jakarta.

Ridwa. HR, 2003, Hukum Administrasi Negara, UII Press, Yogyakarta.

Roeslan, Saleh, 1982, Pikiran-pikiran tentang Pertanggungjawaban (Pidana), Ghalia Indonesia, Jakarta.

Setiawan, 2010, Etika Kebidanan dan Hukum Kesehatan, Trans Info Media, Jakarta.

Soerjono Soekanto, 1986, Pengantar Penelitian Hukum, Cetakan Ketiga, (UI-PRESS) Universitas Indonesia. Jakarta.

Soerjono Soekanto, 1986, Pengantar Penelitian Hukum, Cetakan Ketiga, Universitas Indonesia (UIPRESS), Jakarta.

Subekti, 2002, Hukum perjanjian, Intermasa, Jakarta.

Sudarti, 2010, Endang Khoirunnisa, Asuhan Kebidanan Neonatus, Bayi dan Anak Balita, Nuha Medika, Yogyakarta.

Sadjijono, Memahami Beberapa Bab Pokok Hukum Administrasi, Laksbang.
Usmara, 2015, Peran Pelatihan kedokteran dalam menangani pasiennya, Rajawali Pers, Jakarta.

Sudarsono, 1999, Kamus Hukum, edisi kedua, Rineka Cipta, Jakarta.

Wila, 2010, Chandra Supriadi, Hukum Kedokteran, Mandar maju, Bandung.

Yanti dan W E Nurul, 2010, Etika Profesi Dan Hukum Kebidanan, Pustaka Riham, Yogyakarta.

\section{Peraturan Perundang-Undangan}

Kitab Undang-Undang Hukum Perdata.

Kitab Undang-Undang Hukum Pidana.

Undang-Undang No. 36 Tahun 2009 tentang Kesehatan.

Peraturan Menteri Kesehatan No 28 Tahun 2017 tentang Izin penyelenggaraan praktik bidan.

Undang-undang No. 23 Tahun 1992 tentang Kesehatan.

Peraturan pemerintah No. 51 Tahun 2009 tentang Pekerjaan Kefarmasian.

Kepmenkes RI Nomor 369/Menkes/SK/III/2007 tentang standar Profesi Bidan.

Permenkes RI Nomor 1464/Menkes/Per/X/2010, Pasal 6 dan 18, tahun 2014.

Undang-undang Tenaga Kesehatan

Keputusan Menteri Kesehatan Republik Indonesia Nomor 369 Tahun 2007 tentang Standar Profesi Bidan.

\section{Jurnal}

Akhmad. Marwi, Kewenangan Pejabat Kepala Daerah di Bidang 
Kepegawaian dalam Menyelenggarakan Pemerintahan Daerah, Jurnal IUS, Volume IV, 2011.

Emmy Latifah, "Harmonisasi Kebijakan

Pengentasan Ke-miskinan di Indonesia Yang Berorientasi Pada Millen-nium Development Goals", Jurnal Dinamika Hukum, Vol. 11 No. 3 2011, Purwokerto: Fakultas Hukum Uni-versitas Jenderal Soedirman.

Sari N., Haiti, D., \& Ifrani, I. (2016). Mediasi Penal sebagai Alternatif Penyelesaian Perkara Tindak Pidana Lingkungan Hidup pada Lahan Basah di Provinsi Kalimantan Selatan. Al Adl: Jurnal Hukum, 8(1).

Tedi, Sudrajat dan Agus Mardiyanto, "Hak Atas Pela-yanan dan Perlindungan Kesehatan Ibu dan Anak (Im-plementasi Kebijakan di Kabupaten Banyumas)", Jurnal Dinamika Hukum, Vol. 12 No. 2 Mei 2012, Purwokerto: Fakultas Hukum Universitas Jenderal Soedirman.

Tedi. Sudrajat dan Agus Mardiyanto, Hak Atas Pelayanan dan Perlindungan Kesehatan Ibu dan Anak, Jurnal Dinamika Hukum, Vol. 12, Fakultas Hukum Universitas Soedirman.

Nurhayati, Yati. "Perdebatan antara Metode Normatif dengan Metode Empirik dalam Penelitian Ilmu Hukum Ditinjau dari Karakter, Fungsi, dan Tujuan Ilmu Hukum." Al Adl: Jurnal Hukum 5.10 (2013).
Nurhayati, Yati. "The Application Of Balance Idea In settlement of Doctor Malpractice Case Through Penal Mediation"." The 2nd Proceeding "Indonesia Clean of Corruption in 2020" (2017).

\section{Kamus}

Kamus besar bahasa Indonesia, cetakan ketiga, Balai pustaka: Jakarta, 2005. 
